\title{
Perancangan dan Pembuatan Aplikasi Sistem Klinik Berbasis Web (Studi Kasus Klinik dr. Rida)
}

\author{
Raymond Sutjiadi, ST., M.Kom. \\ Jurusan Teknik Elektro \\ Universitas Kristen Petra \\ Jl. Siwalankerto 121-131, Surabaya \\ raymondsutjiadi@petra.ac.id
}

\begin{abstract}
ABSTRAK
Perkembangan ilmu pengetahuan dan teknologi mendorong perkembangan sektor pelayanan publik dan kesehatan. Klinik merupakan tempat atau sarana yang berfungsi untuk membantu menyembuhkan masyarakat yang mengalami gangguan kesehatan tanpa harus datang kerumah sakit. Namun apabila sistem pelayanannya yang masih menggunakan sistem lama atau manual, tentu dapat menghambat proses penanganan penyembuhan penyakit yang diderita pasien. Oleh karena itu pada tugas akhir ini penulis membuat Aplikasi Sistem Klinik Berbasi Web dengan studi kasus di dr. Rida Klinik. Adapun tujuan dari penelitian ini adalah ingin mempercepat proses kerja pada klinik sehingga pasien tidak perlu lagi menunggu lama untuk antrian yang tidak perlu seperti pengecekan data pasien ataupun rekam medis pasien dan meringankan beban kerja dari pegawai klinik dan dokter sehingga proses kerja menjadi lebih cepat. Dengan merancang aplikasi website yang menggunakan bahasa pemrograman PHP dan data base MySQL.
\end{abstract}

Kata Kunci: Klinik, Sistem Informasi, Web, PHP, MySQL

\section{PENDAHULUAN}

Perkembangan zaman modern seperti saat ini menjadikan manusia menjadi semakin sibuk. Hal ini yang akhirnya mengakibatkan pengaruh pada kesehatan manusia yang sering melupakan untuk merawat dan menjaga kondisi kesehatannya, sehinga mereka sering mengalami gangguan kesehatan pada tubuhnya. Sehingga mereka gampang terserang penyakit, dengan permasalahan tersebut, akhirnya munculah tempat yang dikenal dengan nama klinik. Tempat tersebut berfungsi untuk membantu manusia 
dalam menyembuhkan dan mengatasi gangguan kesehatan yang sedang mereka alami tanpa harus datang kerumah sakit.

Klinik dr. Rida adalah sebuah klinik berdiri pada tahun 2010 dan bertempat di Jalan Deandles Brondong Lamongan. Jenis pekerjaan yang ditangani oleh klinik ini, antara lain konsultasi kesehatan antara pasien dengan dokter, pemeriksaan penyakit umum meliputi demam, batuk, pilek dan lainya, apabila pasien terindikasi penyakit kritis seperti tumor, kanker dan sejenisnya maka klinik tidak melayani atau pasien dirujuk kerumah sakit.

Klinik dr. Rida pada waktu tertentu mengalami kepadatan jumlah pasien yang berkunjung. Hal tersebut menjadikan permasalahan waktu pelayanan dan validitas data dikarenakan klinik masih menggunakan sistem pelayanan secara tradisional yaitu melakukan pencatatan secara manual. Terdapat banyak aspek yang merugikan pasien, misalnya waktu yang dibutuhkan pasien menunggu terlalu lama, pasien harus datang ke klinik terlebih dahulu untuk mengetahui jadwal dokter yang ada, data pasien hilang sehingga harus dilakukan pencatatan kembali, pencarian data pasien yang dilakukan secara manual sehingga pegawai klinik kesulitan membedakan pasien yang pernah berobat dan pasien yang baru, tidak tepat waktu dan kesalahan pembayaran. Pembuatan sistem informasi pada klinik untuk mendukung pelayanan kesehatan diperlukan untuk merancang dan membangun sebuah aplikasi yang dapat mengolah seluruh data pelayanan pada klinik yang memudahkan pengelolaan dan pengarsipan data, pencarian data, serta pencetakan laporan.

Dengan latar belakang tersebut, maka penulis tertarik untuk mendalami pemrograman web dan diwujudkan dengan perancangan dan pembuatan aplikasi sistem klinik berbasis web.

\section{METODOLOGI PENELITIAN}

\section{A. Sistem Informasi}

Sistem Informasi adalah kombinasi dari teknologi informasi dan aktivitas orang yang menggunakan teknologi itu untuk mendukung operasi dan manajemen. Dalam arti yang sangat luas, istilah sistem informasi yang sering digunakan merujuk kepada interaksi antara orang, proses algoritmik, data, dan teknologi . Dalam pengertian ini, istilah ini digunakan untuk merujuk tidak hanya pada penggunaan organisasi teknologi 
informasi dan komunikasi (TIK), tetapi juga untuk cara di mana orang berinteraksi dengan teknologi ini dalam mendukung proses bisnis.

\section{B. PHP}

PHP: Hypertext Preprocessor adalah bahasa skrip yang dapat ditanamkan atau disisipkan ke dalam HTML sejatinya dirancang untuk menghasilkan halaman-halaman web yang dinamis. Arti dari web dinamis sendiri adalah halaman web yang sumbernya menggunakan database sehingga dapat diperbarui secara berkala. Berbeda dengan halaman HTML standar yang apabila ingin diperbarui, maka seluruh isi halaman HTML tersebut harus diunggah..

\section{MySQL}

MySQL adalah sebuah perangkat lunak sistem manajemen basis data SQL atau DBMS yang multithread, multi-user, dengan sekitar 6 juta instalasi di seluruh dunia. MySQL AB membuat MySQL tersedia sebagai perangkat lunak gratis dibawah lisensi GNU General Public License (GPL), tetapi mereka juga menjual dibawah lisensi komersial untuk kasus-kasus dimana penggunaannya tidak cocok dengan penggunaan GPL.

MySQL tidak sama dengan proyek-proyek seperti Apache, dimana perangkat lunak dikembangkan oleh komunitas umum, dan hak cipta untuk kode sumber dimiliki oleh penulisnya masing-masing. MySQL dimiliki dan disponsori oleh sebuah perusahaan komersial Swedia MySQL AB, dimana memegang hak cipta hampir atas semua kode sumbernya. Pendiri MySQL AB adalah: David Axmark, Allan Larsson, dan Michael "Monty" Widenius.

\section{HASIL PEMBAHASAN}

Beradasarkan hasil peneilitian yang telah dilakukan, maka didapatkan hasil aplikasi sistem klinik berbasis web pada klinik dr. rida.

\section{A. Desain Sistem Klinik dr. Rida.}

Sistem Informasi Manajemen pada klinik dr. Rida 


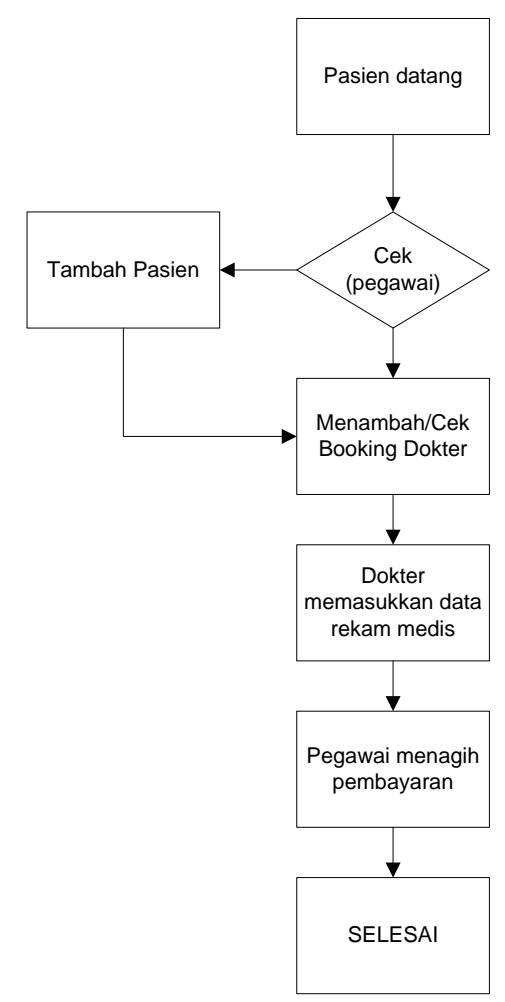

- Context Diagram

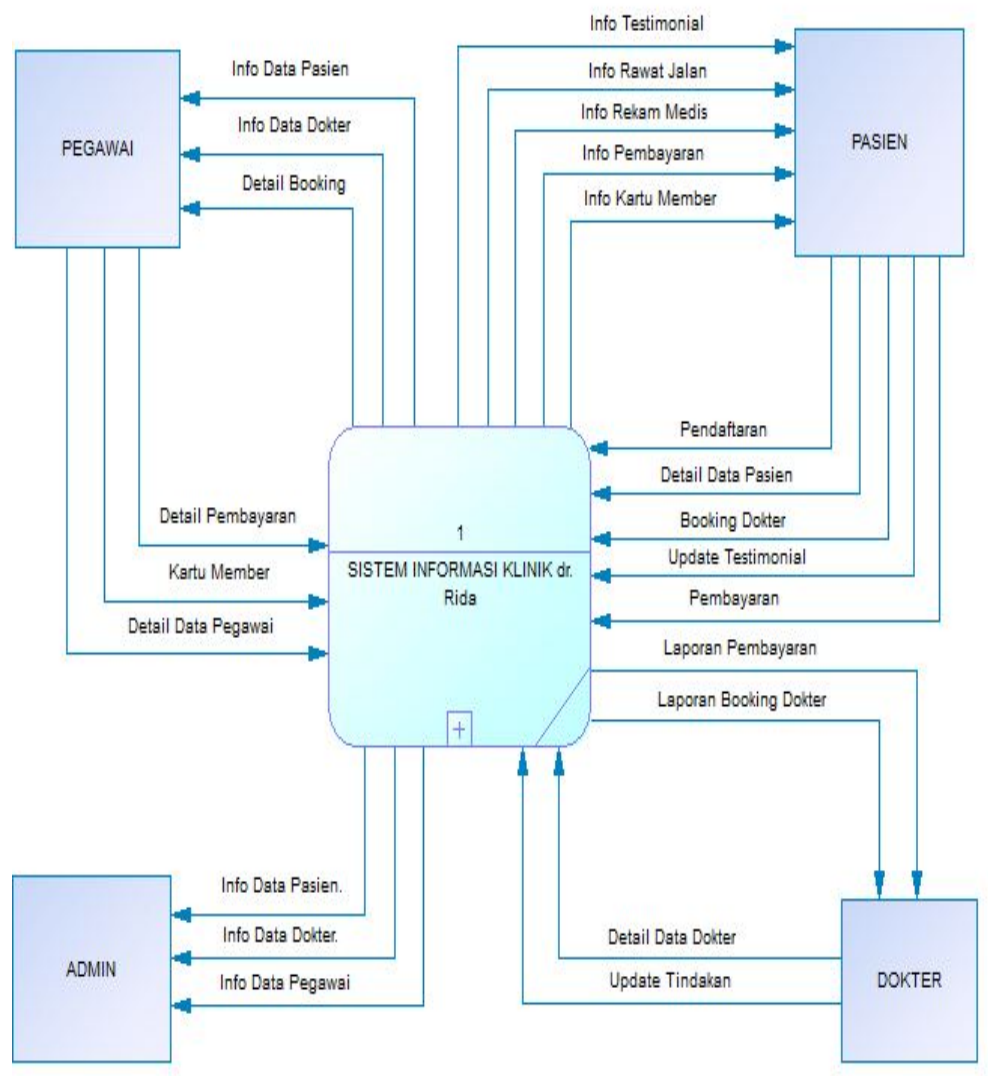


- Entity Relationship Diagram

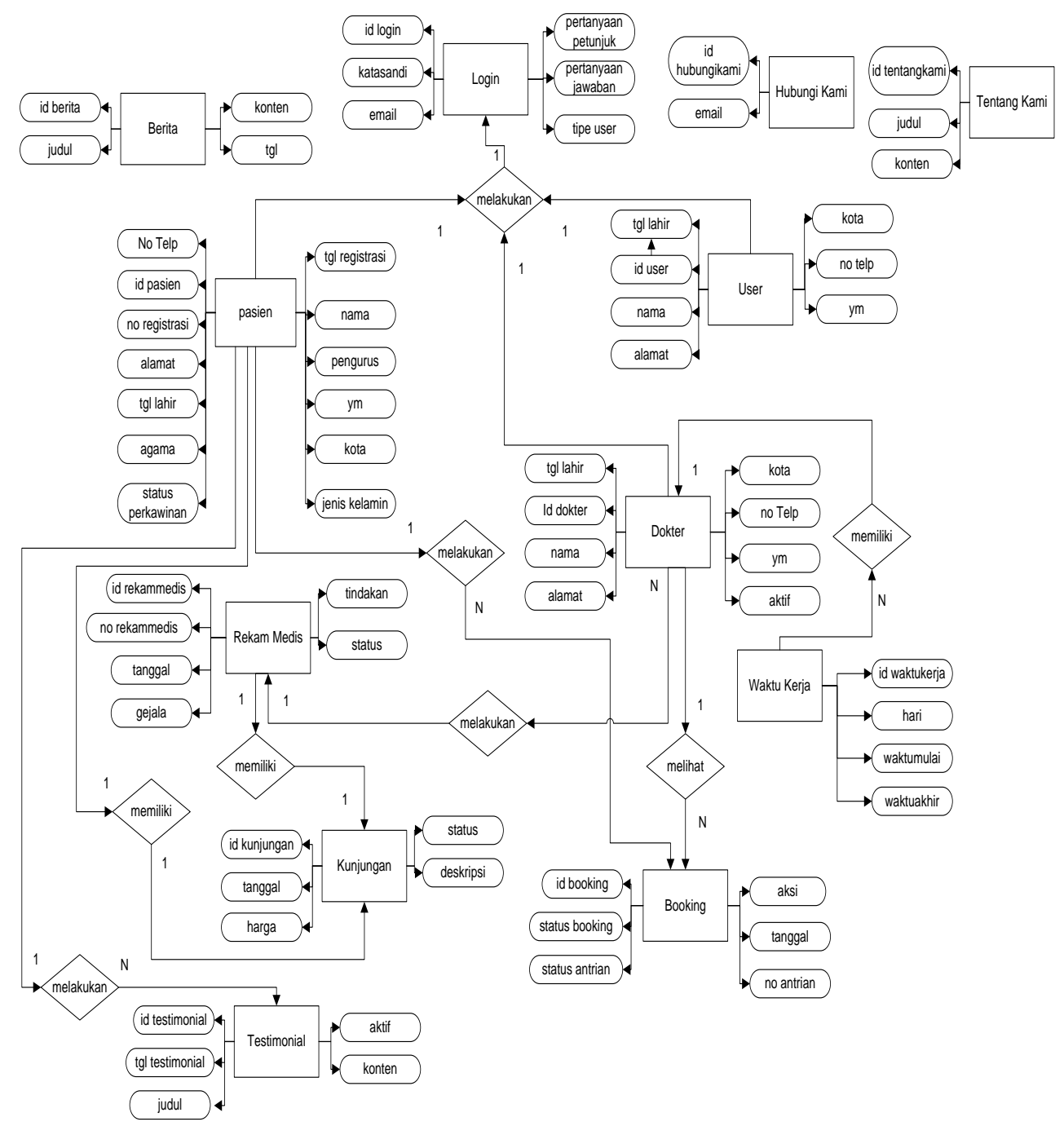

\section{B. User Interface Website}

- Tampilan Beranda

Tampilan Beranda adalah menu awal Tampilan dari website . Didalam tampilan beranda terdapat 5 buah link tampilan layar yaitu testimonial, tentang kami, berita, kontak, dan peta lokasi. Terdapat 7 buah header yaitu beranda, tentang kami, berita, hubungi kami, daftar baru dan login. 


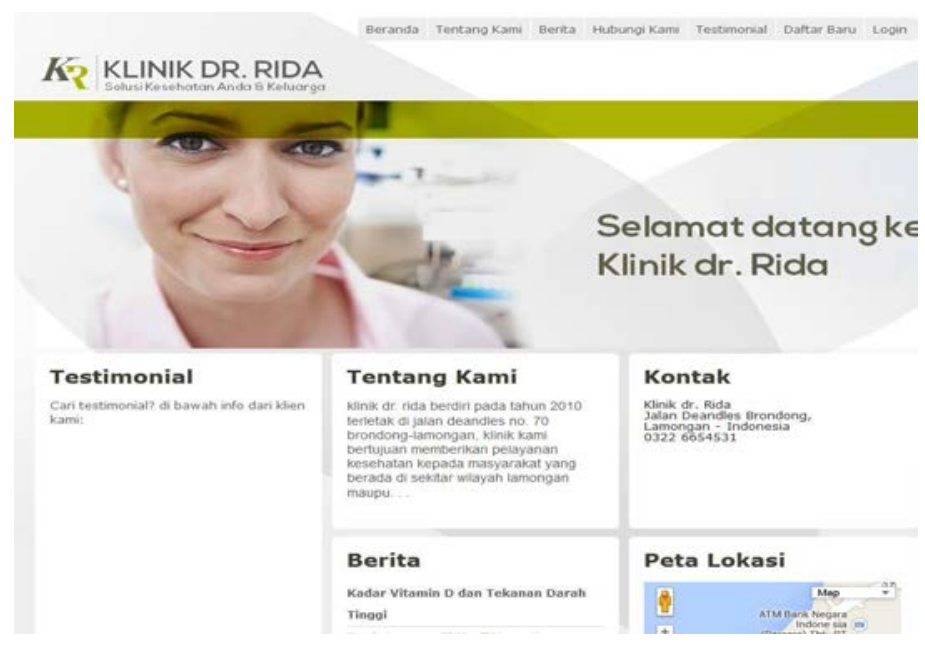

- Tampilan Login

Tampilan login berisi email dan kata sandi

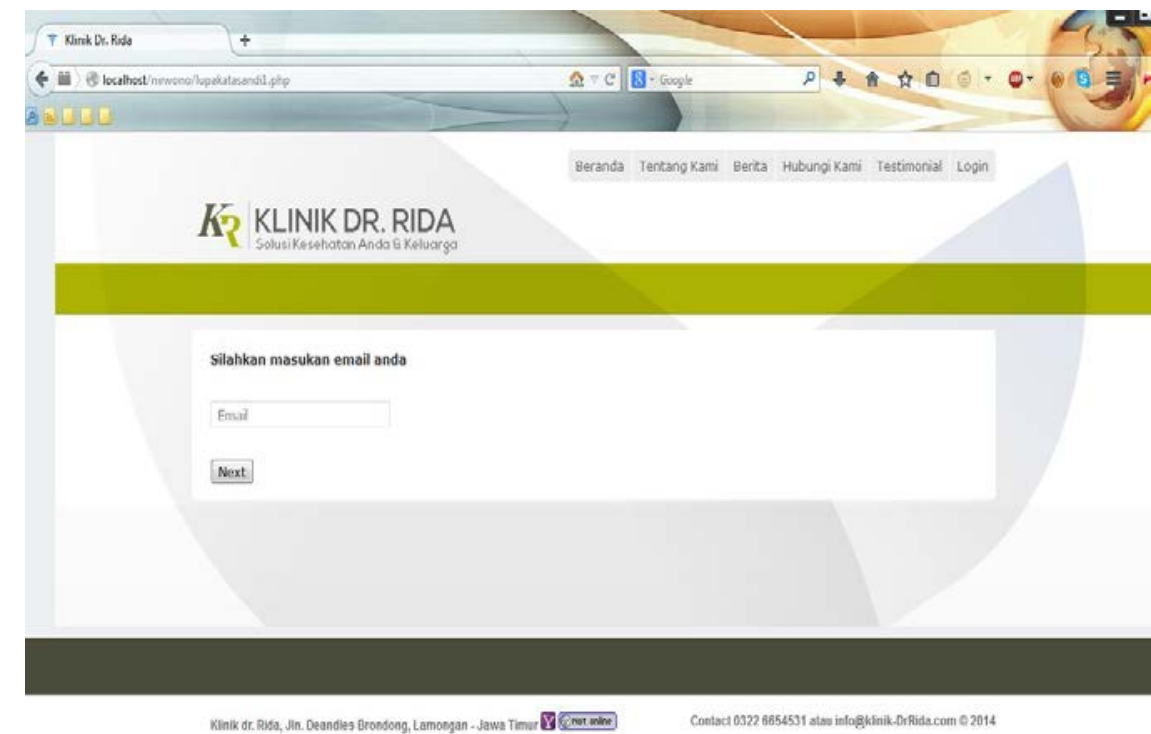

- Booking Dokter

Tampilan booking adalah menu tampilan untuk pasien dimana pasien bisa memilih dokter dan tanggal yang diinginkan.

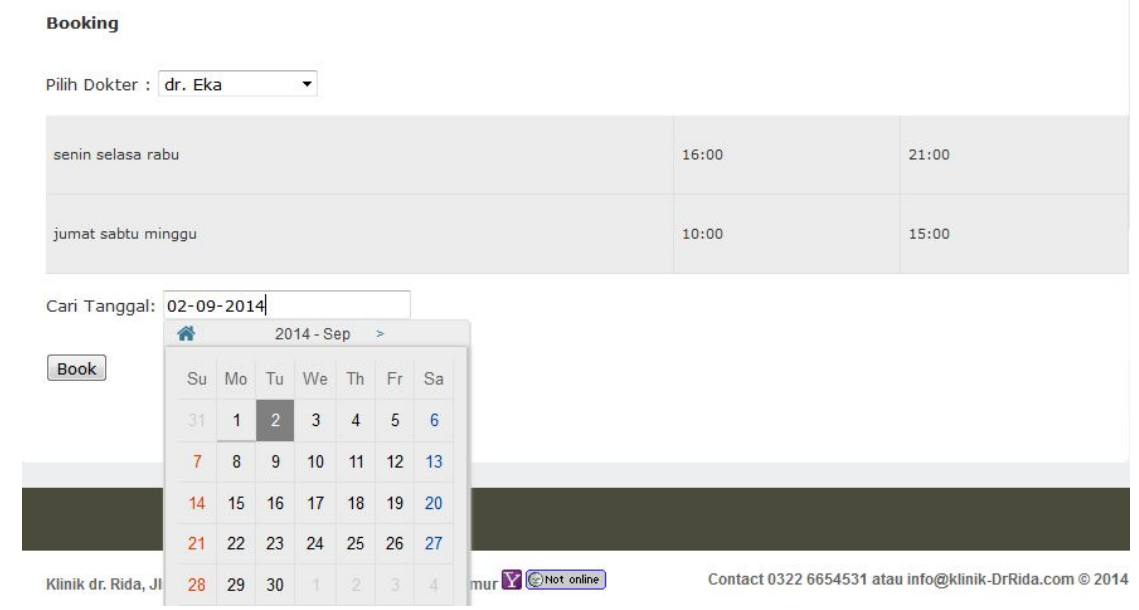


- Rekam Medis

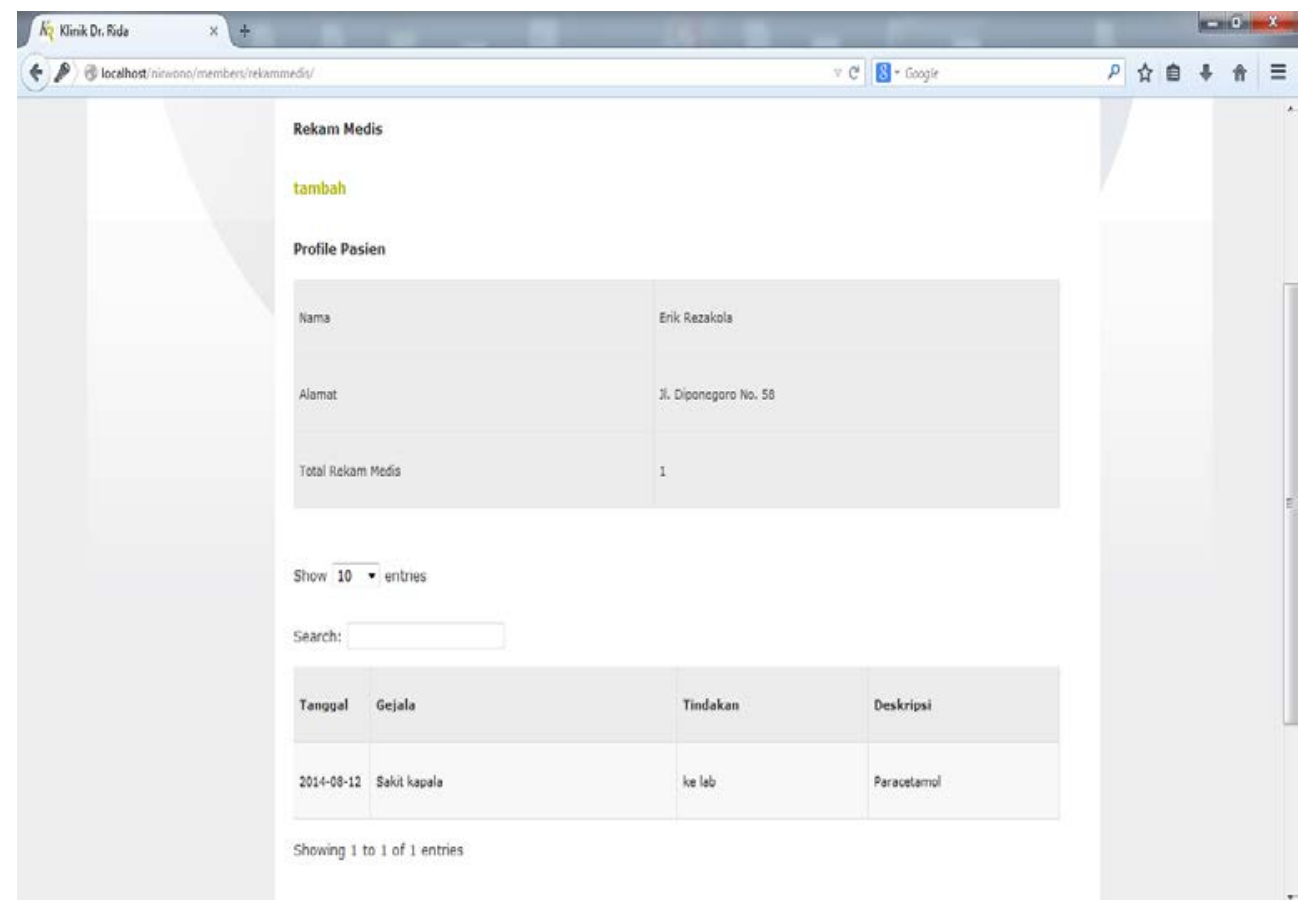

Tampilan rekam medis adalah menu tampilan untuk dokter dimana dokter melihat indeks data rekam medis pasien, dari indeks dokter bisa melihat riwayat rekam medis pasien apakah pasien pernah berobat atau pasien baru pertama kali datang ke klinik, kemudian dokter menambah rekam medis pasien yang berisi gejala dan tindakan dokter, kemudian dokter menentukan harga dan deskripsi.

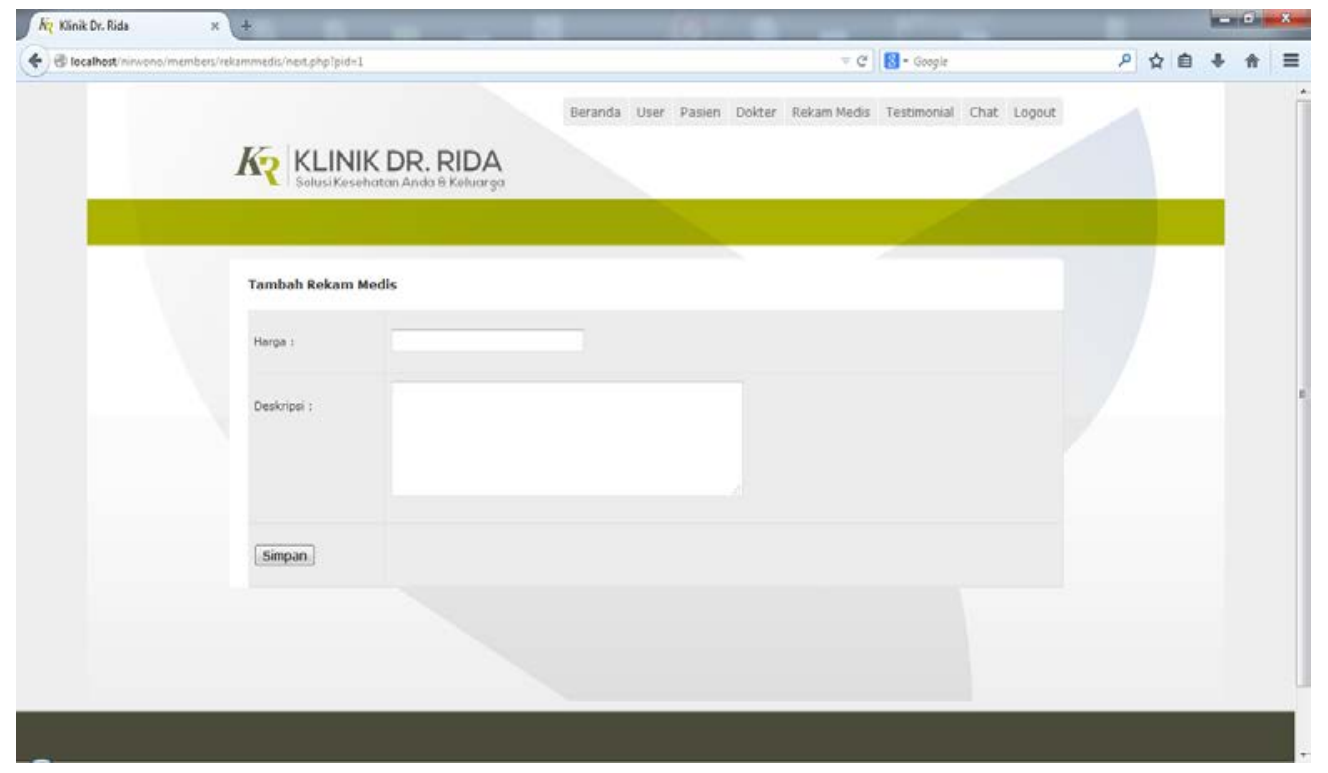


- Tagihan

Setelah dokter melakukan input data rekam medis pasien maka selanjutnya adalah tugas karyawan untuk mengecek dan melakukan transaksi tagihan kepada pasien berisi tanggal, gejala tindakan dan status.



Setelah melakukan transaksi tagihan pasien bisa langsung meninggalkan klinik. Maka berakhir pula proses kegiatan yang ada pada klinik dr. Rida.

\section{KESIMPULAN}

Terdapat beberapa kesimpulan yang dapat diambil dari proses pembuatan aplikasi sistem klinik berbasis web pada klinik dr. rida. Kesimpulan yang dapat diambil antara lain:

- Proses pendaftaran antrian pasien lebih efektif karena pasien bisa melakukan dengan booking secara online, dokter bisa mengetahui pasien yang telah booking pada laporan booking sehingga bisa melihat terlebih dahulu pasien yang akan ditemui.

- Dengan dibuatnya aplikasi ini pegawai dapat melakukan pengolahan data master sehingga lebih cepat dan mudah, proses pencatatan antrian lebih cepat.

- Aplikasi ini bisa mengatasi permasalahan kegiatan yang ada pada klinik secara otomatis. 


\section{REFERENSI}

[1] Al Fatta , Hanif (2007). Analisis dan Perancangan Sistem Informasi. Yogyakarta : Andi..

[2] Boumprey, Frank. Professional Stylesheets for HTML and XML. Chicago: Wox Press, 1998.

[3] Kadir, Abdul (2004). Konsep dan Tuntunan Praktis Basis Data. Yogyakarta : Andi.

[4] Kusrini (2007). Strategi Perancangan dan Pengelolaan Basis Data. Yogyakarta : Andi

[5] Nugroho, Adi (2004). Konsep Pengembangan Sistem Basis Data. Bandung : InformatikaYogyakarta, 2010.

[6] Peranginangin, Kasiman. (2006). Aplikasi WEB dengan PHP dan MySQL. Yogyakarta : Andi

[7] Putri, Eka, Dewanti (2011). Sistem Informasi Manajemen klinik Gigi. Yogyakarta : Tugas Akhir Teknik Informatika UII

[8] Solichin, Achmad (2004). Pemrograman Web dengan PHP dan MysQL. Jakarta : Universitas Budi Luhur. 